\title{
Mapping cultural policy in Portugal: From incentives to crisis
}

José Luís Garcia, João Teixeira Lopes, Teresa Duarte Martinho, José Soares Neves, Rui Telmo Gomes \& Vera Borges

To cite this article: José Luís Garcia, João Teixeira Lopes, Teresa Duarte Martinho, José Soares Neves, Rui Telmo Gomes \& Vera Borges (2016): Mapping cultural policy in Portugal: From incentives to crisis, International Journal of Cultural Policy, DOI: 10.1080/10286632.2016.1248950

To link to this article: http://dx.doi.org/10.1080/10286632.2016.1248950

曲 Published online: 06 Nov 2016.

Submit your article to this journal $\widetilde{ }$

Џ Article views: 39

Q View related articles $\sqsubset$

View Crossmark data $\nearrow$ 


\title{
Mapping cultural policy in Portugal: From incentives to crisis
}

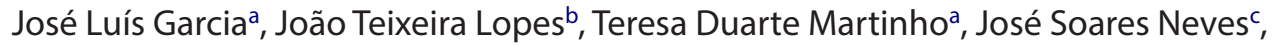 \\ Rui Telmo Gomes ${ }^{\mathrm{c}}$ and Vera Borges ${ }^{\mathrm{d}}$
}

anstituto de Ciências Sociais, Universidade de Lisboa (ICS-ULisboa), Lisboa, Portugal; bFaculdade de Letras da Universidade do Porto (FLUP), Porto, Portugal; ' Instituto Universitário de Lisboa (ISCTE-IUL), Centro de Investigação

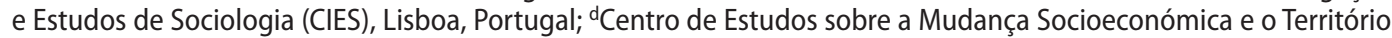
(DINÂMIA'CET), Instituto Universitário de Lisboa (ISCTE-IUL), Lisboa, Portugal

\begin{abstract}
Taking into account the course of cultural policy in democratic Portugal, and against the backdrop of the international crisis of 2008 and the sovereign debt crisis of 2011, this article seeks to interpret recent changes in the cultural sector in Portugal. Using both qualitative and quantitative methods it focuses on three main aspects: institutionalisation of democratic cultural policy; government funding; cultural organizations and facilities. The 2008 crisis put an end to a period in which investment tended to grow. We place Portugal in the broader European context, concluding that the Portuguese cultural scene may once again diverge from that of other European countries.
\end{abstract}

\section{ARTICLE HISTORY}

Received 10 November 2015

Accepted 11 October 2016

\section{KEYWORDS}

Portugal; cultural policy; public expenditure on culture; systems of cultural administration; European Union

\section{Introduction}

The main object of this article is to provide an overview and assessment of how institutional and infrastructural conditions have affected or contributed to support for the cultural sector in Portugal over the last twenty years. With a view to achieving a broad understanding of how culture has evolved and changed, the article maps and discusses a number of topics, from institutionalisation of democratic cultural policy to State and municipal funding, also providing an overview of cultural organizations and facilities. Wherever possible we have sought to make comparisons between Portugal and other European countries. The study combines quantitative approaches such as the use of statistics and putting together indicators with qualitative elements such as documentary analysis.

The State's responsibilities for cultural affairs are defined in the Constitution of the Portuguese Republic, approved in 1976, two years after the overthrow of the dictatorial regime of the Estado Novo. The broad aims defined by the Constitution are to ensure creative freedom, that all citizens should have access to culture and that Portuguese culture be supported in foreign countries. Early democratic governments were focused on overcoming severe developmental weaknesses and establishing the basic principles of a welfare state (Santos 1994; Barreto 1996; Santos et al. 1998, Viegas and Costa 2000; Conde 2000). Their investment priorities thus lay in health and education. In the latter area in particular, and despite the recovery achieved since the advent of democracy, structural problems persist in Portugal. Of the 28 member-states of the European Union, Portugal has the second lowest percentage of individuals who have completed secondary education: in 2014, less than half of the Portuguese population had reached this level of schooling, as in Malta. In the same year, Portugal had the fourth highest rate (17.7\%) of early dropout from school and training. ${ }^{1}$ Even though there has been significant progress 
in dealing with those deficiencies over the last decade, Portuguese society still has lower percentages in these areas than the EU average. Portugal shares these educational disparities with countries like Malta, Spain and Italy. ${ }^{2}$

It was from the 1980s onwards, when Portugal joined the European Economic Community in 1986, that culture became a recurrent topic in political discourse of all stripes. In the mid-90s, government attempted to make culture independent by creating a Ministry. In recent years this aim lapsed: in 2011, culture was subsumed under the Presidency of the Council of Ministers (Cabinet Office), to be represented by a Secretary of State for Culture. With the parliamentary elections of 2015, which produced a Socialist party government supported by two other parties on the left, the culture sector was once again overseen by a Ministry of Culture. This change represented a reversal of the tendency to undervalue the independence of culture in political terms which had existed under the coalition of the Social Democratic and Popular parties (PSD/CDS-PP) from 2011 to 2015.

Analysis of constitutional government manifestoes reveals a consistent range of stated objectives for the culture sector. Those objectives include safeguarding heritage; ensuring universal access to culture; supporting the creative arts, cultural production and dissemination; cultural decentralisation and internationalisation of Portuguese language and culture. It should be noted that Portugal is a member of the platform known as the CPLP (Community of Portuguese-speaking Countries), an international organisation made up of countries having Portuguese as their official language: Angola, Brazil, Cabo Verde, Guiné-Bissau, Mozambique, Portugal, São Tomé e Príncipe, East Timor and Equatorial Guinea. ${ }^{3}$ More recent government aims have included measures for promoting the creative industries and incentives to bring culture closer to the economic sphere.

With its particular historical trajectory, Portugal has implemented cultural policies in line with the stages which Pierre-Michel Menger sees as cutting across culture policies in various European countries, although there may be some asynchronicity along that common pathway. A first stage involving a policy of systematic cultural support and promotion gave way to a time of gradual decentralisation in forms of state intervention and a diversity of purposes and functions, leading to the present-day situation in which there is an increasing tendency to justify cultural policy in terms of its contribution to economic growth (Bennett 2009; Menger 2010; Morató 2012). The collapse of state collectivist and dictatorial regimes in Portugal and Spain and in Eastern Europe gradually blurred the marked differences seen in cultural policies until that time.

Given that among the member-states of the European Union Portugal has suffered most sharply in the financial crisis, what repercussions have there been in terms of public expenditure on culture? How have the objectives of the cultural facilities (libraries, cine-theatres, museums, archives) built or improved during the growth phase of public spending on culture been pursued and maintained? What were the effects of the structural problems of Portuguese society, such as the low levels of educational attainment, on the cultural practices of the Portuguese, including access to and use of digital media? What are the extent and real value of flexible working arrangements in a context where some careers in the cultural sector are hard to maintain? These questions show how relevant it is to assess that which was achieved in a growth cycle, in contrast to a time of budget restrictions and discontinuity.

The article begins by mapping the process of institutionalisation of democratic cultural policy and the stages in the formation of the system of cultural governance. It continues with an analysis of financial resources and an assessment of the degree of policy intervention by central and local government. The third section deals with cultural organizations and facilities operating in Portugal, its main aim being to understand their dynamics and how they have evolved over time; part three offers also an interpretation of available data on attendance at cultural facilities. The aim is to establish connections between the various sections in order to reach a deeper understanding of the general transformation and its consequences. The final part of the article outlines some conclusions, the main one being that two antagonistic trends are present, with certain observable processes taking place in between them: (i) from the 1990s until 2008 there was overall growth in investment, in several areas; (ii) the chain of events resulting from the international financial crisis of 2008 and the subsequent sovereign debt crisis of 2011 necessarily put a brake on earlier tendencies. 


\section{Institutionalisation of democratic cultural policy in Portugal}

Up until the revolution of 25 April 1974, Portugal had an authoritarian regime. In addition to restricting democratic rights and enforcing censorship, it was a regime which limited both cultural and artistic endeavour and contact with cultural trends and experiments taking place in other countries, particularly those in Europe. The period from 1974 to 1976 was a turbulent time of transition to democratic parliamentary government, since the end of which, in 1976, constitutional governments have held power up to the present day. There has been rotation among these governments between the left, represented by the Socialist Party ${ }^{4}$ (PS), and the right, mainly represented by the Social Democratic party ${ }^{5}$ (PPD-PSD). A brief summary of that rotation in government involves the following cycles: PS, between 1976 and 1978; PPD-PSD (in coalition with Centro Democrático Social, ${ }^{6}$ CDS, another right-wing party) between 1980 and 1983; PS in coalition with the PPD-PSD, between 1983 and 1985; PPD-PSD from 1985 to 1995; PS from 1995 to 2002; PSD (with CDS-PP), between 2002 and 2005; PS, between 2005 and 2011; PSD with CDS-PP, from 2011 to 2015; PS, from the end of 2015.

Since the establishment of parliamentary democracy there have been two key socio-economic events. The first was Portugal's accession to the European Economic Community in 1986. The second was the international crisis of 2008, the effects of which were particularly severe in a number of countries, including Portugal, which felt the effects of the crisis with particular force after the international sovereign debt bailout in 2011. In that year the 18th constitutional government (a Socialist party government), negotiated a financial adjustment programme with the so-called 'troika' - formed by the European Commission, the European Central Bank and the International Monetary Fund - which assessed Portugal's national accounts and defined the country's borrowing needs. Portugal's financial situation was monitored by the troika between 2011 and 2014, with regular visits by its members.

As previously mentioned, it was from the 1980s onwards that culture became a recurrent topic in political discourse of all stripes, even if in a somewhat unsystematic manner and without it being considered an area meriting independent status in public policies.

In the 1980s, the promotion of a national reading and literacy policy became a priority, mainly because the country's literacy levels were substantially below the European average. This scenario explains why the libraries sector was reorganized well before other cultural domains, with the launching in 1987 of the Public Reading Network (Rede de Leitura Pública), the first national network of cultural facilities. A lasting tendency in culture policy, common to all governments since 1987, has been the establishment of partnerships between central and local government, with a view to setting up cultural facilities - such as libraries and cine-theatres - all over the country. The consensus on the importance of facilities networks can be explained by the shared conviction, on the left and right, that creating and enjoying culture is valuable in itself, on the one hand, and on the other by the idea that partnership in support of those networks reduces the financial burden on central government.

A Ministry of Culture was set up for the first time under the ninth constitutional government (19831985), which was ideologically positioned in the centre. From 1985 to 1995, under Social Democratic party government, there was no culture ministry, but it was re-established under the 13th constitutional government (Socialist party) and endured until 2011. In 1995, in addition to having its own budget, the Ministry of Culture was endowed with autonomous departments whose aims were to define policies for specific areas. The Ministry's strategy covered five main areas: books and reading; heritage; creative work; decentralisation and internationalisation. This first socialist government following a period of more right-wing government was guided by the pattern of intervention adopted by Jack Lang, minister of culture in France in the 1980s, in particular in regulating the price of books and supporting the national film industry. In Spain too there was a notable influence of French cultural policy in the definition of a cultural policy 'more focused on defending its own identity' (Ariño Villarroya 2015, 1373).

After a period of more vigorous intervention from 1995 to 2000, governments gradually invested less and less in culture, starting with lower financial appropriations, as we shall see in the following section, and extending to the conception and implementation of co-ordinated strategies for the sector. Nevertheless, in the 2000s the country benefited from the injection of funds deriving from membership 
of the European Economic Community/European Union, particularly in the 2000-2006 period, which saw a specific programme for culture, the Operational Programme for Culture, as part of the Third Community Support Framework (POC/QCA-III).

The central government reforms carried out by the 17th constitutional government in 2006 (known as PRACE), and the sweeping reorganization of the Ministry of Culture, were the signal for dismantling the structure which had been set up in 1995: the restructuring which took place in 2006 with the stated aim of rationalising resources basically led to the reduction in the number of departments through mergers between them, with the consequent loss of autonomy for sectoral policies.

Although there are differences in the discourse and priorities set out in party manifesto goals, as mentioned in the Introduction, it is generally fair to say that Portuguese state intervention in the culture sector has involved more consensus and continuity than discontinuities. There are three fundamental reasons for this trend, which does not mean that there is a uniformity of views or absence of debate. First, the very parlous state of culture, which was the starting point for defining and implementing public policies in the culture sector, encouraged political consensus; in addition, all parties wanted to increase the number of cultural facilities. Secondly, central and local government dependence on EU funding and even guidance, which Portugal has always endeavoured to observe, also encouraged continuity rather than change (Soromenho-Marques and Pereira 2015; Silva, Babo, and Guerra 2015; Martinho, 2016). Thirdly, governments of different ideological persuasion have all made cuts to culture budgets, especially in the wake of the financial crisis of 2008, even though the Socialist Party in 2015 may have restored the Ministry of Culture and thereby restated a characteristic feature of its administrations, the recognition of culture as a specific area for public policies.

A good example of the convergence arising out of budgetary constraints is the management of the only opera house in Portugal, the São Carlos National Theatre (Teatro Nacional de São Carlos). The statutory definition and funding model for this theatre have been a constant problem for those in charge of culture in different governments. While in the 1990s there was a visible difference in the PSD and PS choice of managers - the former tending to experiment with more liberal, privatising models, the latter preferring the form of the independent state body or institute, in the 2000s, as culture budgets were gradually cut, there was increasing convergence between the socialist and social democratic parties in adopting for Portugal's only opera house the methods defined in the so-called new public management model (Martinho and Matos 2014).

It is important to highlight the significant role of the municipalities in the institutionalisation of cultural policy, not least on account of the strong growth in local government spending on culture since 1986 (the first year for which data is available) as a result of how important the concept of decentralisation became in cultural policy. Since 1995, this has become the main source of public funding for cultural activities (Santos et al. 1998). This trend is described in greater detail in the following section. The importance of the local government role in the cultural sector is also reflected in the fact that, in line with the sought-after policy of decentralisation, municipalities are responsible for managing a significant proportion of cultural facilities like public reading libraries, archives and municipal museums, and cine-theatres, many of them multi-purpose.

Even though there are observable differences between right-wing, centre-left and left-wing local governments in the way they reconcile identity, expression and public service in the field of culture (Albuquerque 2011), there is a prevailing model of intervention among the different municipalities which is guided by these general principles: heritage conservation and improvement; diversification of supply of cultural goods; and developing audiences for culture (Silva, Babo, and Guerra 2015). And just as governments in more recent times have increasingly supported the creative industries and the cross-fertilisation of culture and the economy, so too in some municipalities the range of objectives outlined above has incorporated a redefinition of the cultural sphere as part of the local economy, stressing the linkages between cultural policy and other public policies, and with culture being closely tied in with tourism, amongst other areas (Ibid.). 


\section{The main aspects of the regulatory role of the State}

An overview of legislation for the cultural sector over recent decades reveals the diversity of that legislation's aims and the many areas in which governments have sought to apply those laws: conservation and preservation, creative activity and dissemination, and co-ordination with policies for larger territories such as the European Union. The vast amount of legislation available shows the many roles the State may play in culture, although it is its role as regulator which prevails. Thus the government may adopt the following roles: (i) patron, to the extent that it funds artistic creativity (by way of tender or direct commissions from creators and writers); (ii) regulator, when it makes specific decisions on how heritage is to be conserved or preserved and how libraries, museums, archives and entertainment areas are to operate (by defining rules for protecting fixed and moveable assets and for the operation of cultural spaces); (iii) entrepreneur, when it is the promoter of artistic productions (e.g. national theatre companies and some artistic groupings (ballet companies, orchestras) administered by culture departments); (iv) market interventionist, when it makes arrangements to favour the circulation of certain cultural goods over others (by way of example, through fixed pricing for books) (Cummings and Katz 1989).

A comparative study of State intervention in recent years in the cultural sector in eight European countries with differing political, economic and cultural trajectories - Portugal, France, United Kingdom, Italy, Holland, Finland, Poland, Hungary - showed the extent to which there are both common elements which cut across them all and differentiating characteristics. ${ }^{7}$ Cross-cutting elements include joint ministerial responsibility for culture with other areas (communications, education, tourism, sport); inter-ministerial co-operation initiatives; institutional models designed to render administrative departments and cultural institutions more flexible and self-financing. The UK stands out from this group in that there is a greater tendency for privatisation and openness to market forces, as shown by the lack of any specific measures relating to working conditions or social security for artists and fewer tax breaks for creators and culture workers. In contrast, France has a more State interventionist profile, as demonstrated, amongst other measures, by the status of national theatres as public entities and the existence of specific social security arrangements for workers in the cultural sector who are mainly employed on an intermittent, casual basis.

Like some other countries, Portugal has tried a combination of the practices and tendencies identified in those two models of state action. In actual fact, and bearing in mind that other countries moved from a strongly interventionist State model to models more closely based on public-private partnerships during the 1980s, Portugal has pursued a somewhat irregular path, having come later and in a more limited way to the State as a public service provider and to an interest in linkages between the private and public sectors. It should be noted that this interest has been reinforced by the so-called 'new public management model', which has been favoured as a result of declining state resources. This is addressed below.

\section{The public funding of culture: from incentives to degrowth}

This section analyses financial resources, which are another basic tool of public policies, alongside legislative means, with a view to situating the extent of policy intervention, and the guidelines and objectives behind it.

In the last few decades of the twentieth century - in a trend which went counter to the rapid growth in public spending on culture from 1960 onwards - there was a period of stagnation and even reversal, as a result of more liberal influences in public policy. In the first decade of the twenty-first century, however, the tendency in most countries was one of growth (Klamer, Petrova, and Mignosa 2006, 84-87), only recently frustrated by the international financial crisis from 2008 on. A number of studies have sought to examine the likely impact of the crisis on public funding of culture in Europe (Council of Europe 2009; Inkei 2010, 2011; SICA 2010). Falls in budget provisions reflected measures such as the reduction of subsidies to national institutions and independent organizations, cuts in infrastructure investment 
programmes, and the suspension of, or significant reduction in, support to creative projects. On another level, cuts in state support to the arts are part of a more general trend towards social change in which interventions of a more liberal type are favoured (Alexander and Bowler 2014, 8).

In Portugal, it was only after the introduction of democratic government in the mid-70s that government intervention in various cultural domains became more marked, together with the consequent provision of State funding. This acceptance was based on a continuous increase in expenditure, of which the following are the main elements: culture departments, in central government; and municipalities, in local government (Santos et al. 1998). The intermediate regional level is not part of the country's administrative structure. As we will see below, these trends continued into the beginning of the twenty-first century. In line with the newly stated policy of decentralisation - together with the fact that municipalities were able to draw on funding from a variety of local, regional, national and international sources (D'Angelo 2000, 66) - most expenditure since the 1990s has taken place at the municipal level (Santos et al. 1998, 94-100, 109-110). Like other sectors of Portuguese society, culture also benefited from the injection of funds deriving from membership of the European Economic Community/European Union from 1986 on, particularly in the 2000-2006 period, which saw a specific programme for culture, the Operational Programme for Culture, as part of the Third Community Support Framework (POC/QCA-III).

At the turn of the century expenditure held stable for a few years. At the end of the first decade, the clearly dominant tendency is for retraction, first in central government and a little later at the local level. This trend can be explained by the successive reforms of central government and, more recently, by the international crisis of 2008. The crisis sharply affected a number of countries, including Portugal, which experienced its effects with special severity after the international bailout of its sovereign debt in 2011.

The first two stages - growth and stabilization - coincided with significant investment in cultural infrastructure, which the country had long been lacking, namely libraries, archives, museums and venues for the performing arts. This investment tended to be made under network facilities programmes (Silva 2004), based on linkages between central and local government. Thus the recent contraction in expenditure has also meant the end of a period of public policies aimed at modernising those infrastructures. Even then, we cannot fail to note that the large cuts in spending - which was already relatively low in comparison to other countries (Pinto 2012) - led, at both levels of government, to a dwindling in the number of programmes ${ }^{8}$ for government intervention and support to the artistic and cultural fabric. This, it should be added, at a time when it was to be expected that a new batch of policies would be introduced to fulfil previously defined missions, amongst other priorities, and ensure the regular operation of facilities previously built or refurbished.

The beginning of the twenty-first century in Portugal, as mentioned above, was the high point of a long growth trend in government spending on culture. Until 2008, at current prices, that trend remained relatively stable, although a tendency to decline was already visible, and attenuated in 2005 and 2008 (Figure 1). These two years were key from the point of view of the Operational Programme for Culture (POC/QCA-III), having seen significant investment in heritage and the performing arts. From 2009 onwards, the dominant note is one of continuous reductions, with departmental spending in 2012 (134 million Euros) touching a level well below that recorded in 2000 (233 million Euros). This trend persisted, with minor variations, throughout the period of the PSD/CDS-PP coalition government (132 million Euros in 2015).

There has also been a significant decline in the percentage of departmental spending on culture in total State spending. The 2012 value $(0.23 \%)$ is less than half that of $2000(0.59 \%)$ and declines in the subsequent years $(0.21 \%$ in 2015$)$. In the time period in question, governments tended to be of a centre-left orientation ideologically (PS, 1999, 2005 and 2009), centre-right (PSD, 2002) and from 2011 until 2015 more to the right (coalition between the PSD and the CDS-PP). The change in government which emerged from the elections of 2015, the Socialist party taking power with the support of parties on the left did not affect the trends observed in previous years. The initial budget (158.3 million euros) was only slightly higher, by 1.9 million euros, than the 2015 budget. ${ }^{9}$

There has been strong growth in municipal spending on culture since 1986, the first year for which data is available. A feature of that trend over the last two decades has been a pattern of expenditure 


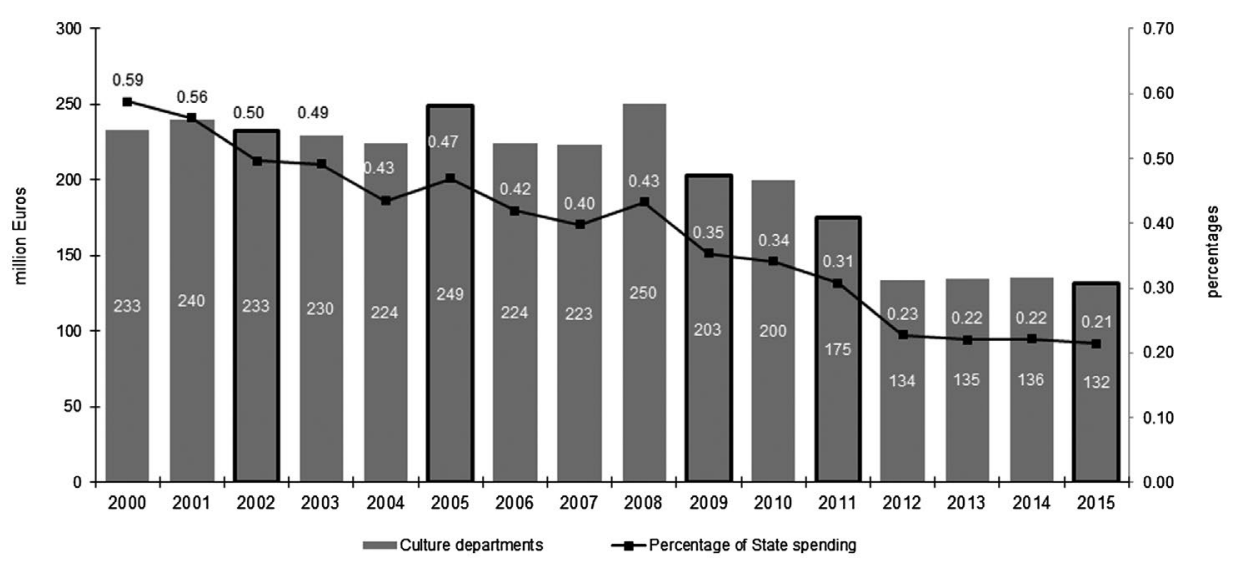

Figure 1. Actual spending by culture departments and proportion of State spending (2000-2015) (million Euros and percentages). Source: Ministério da Cultura/Secretaria-Geral and Secretário de Estado da Cultura/Gabinete de Estratégia, Planeamento e Avaliação Culturais; Conta Geral do Estado (State spending).

Notes: Ministério da Cultura (Ministry of Culture) until July 2011, Secretário de Estado da Cultura (Secretary of State for Culture) from that date until oct 2015; Ministério da Cultura from that date on; election years circled in black.

which falls off in the two years after each year in which there is an election, followed by growth in the final two years, a pattern which thus coincides with the timings of elections and which may reflect the greater efficiency with which newly elected politicians manage investment projects (Neves 2010). Although this pattern goes a long way towards explaining negative trends during this period, in recent years $^{10}(2010-2014)$ there has been a noticeably sharper drop, added to which, for the first time, there has been a reduction in expenditure for five years running (Figure 2).

Spending on culture has always represented over $5 \%$ of total Portuguese municipal budgets. The years 2010-2014, coinciding with the period of sharpest reductions in public spending, are those which saw the lowest percentages, with the minimum of $4.9 \%$ in 2014. Expenditure is divided between heritage (particularly museums), performing arts (especially venues, main domain of investment between 2003 and 2006) and libraries and archives (particularly libraries). These three domains represent 67\% of spending on culture in 2014.

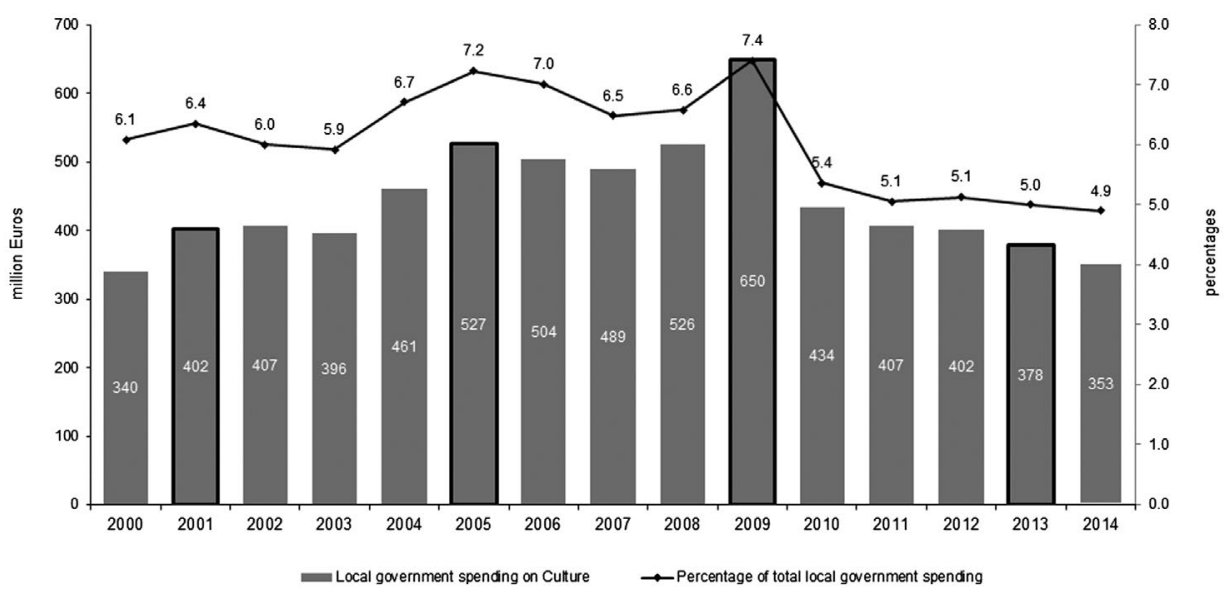

Figure 2. Spending by Portuguese local government authorities on culture, and percentage of total spending (2000-2014) (million Euros and percentages). Source: Instituto Nacional de Estatística (Statistics Portugal), Inquérito ao Financiamento Público das Atividades Culturais das Câmaras Municipais (2000-2012) [Survey on Public Financing of the Cultural Activities of Municipalities (20002012)]; Inquérito ao Financiamento Público das Atividades Culturais, Criativas e Desportivas pelas Câmaras Municipais (2013-2014) [Survey on Public Financing of the Cultural, Creative and Sporting Activities of Municipalities (2013-2014)].

Notes: Election years circled in black. There were 308 Portuguese municipalities in this period. 


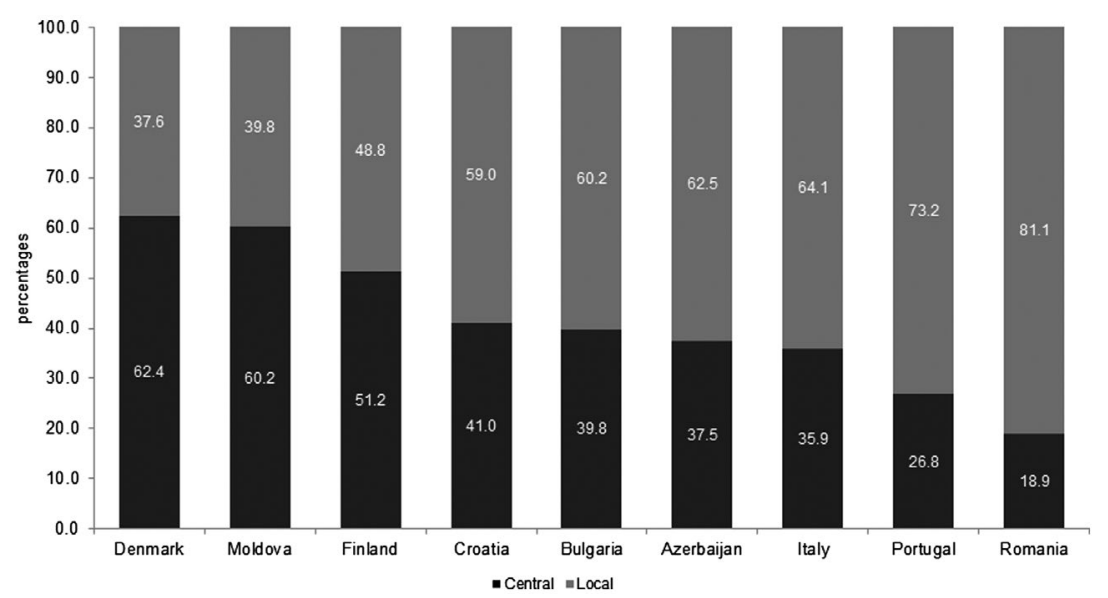

Figure 3. Total public spending on culture by type of government (2009/2011) (percentages). Source: Council of Europe/ERICarts, Compendium of Cultural Policies and Trends in Europe, 14th edition, 2013.

Note: For comparative purposes only countries with spending by local and central governments have been included.

From a comparative European point of view, one of the main features is the diversity of guiding principles, funding systems, government cuts and forms of territorial organisation (Inkei 2011; De Voldere et al. 2013, 27-43). This makes it difficult to find and complete the data which the work of harmonisation of official statistics continues to seek to overcome (Bina et al. 2012). In this connection, the Compendium of Cultural Policies and Trends in Europe ${ }^{11}$ is one of the main sources available. It confirms that public spending on culture in Portugal is one of the lowest among the countries covered. Based on data available (for 2010/2013), per capita spending (€69) is one of the lowest. Portugal's spending on culture as a proportion of total public spending $(0.9 \%)$ is below the average for the comparison in question (1.54\%). At $0.42 \%$, Portugal is likewise below the $0.56 \%$ European average in terms of culture as a percentage of Gross Domestic Product, higher only than countries such as Greece $(0.23 \%)$, Germany (0.38\%, somewhat surprisingly) and Ireland (010\%), as was already the case in the 2000-2005 period (Klamer, Petrova, and Mignosa 2006, 28).

In the countries which have local and regional levels of government, the share of expenditure at those levels is higher than that of central government (Klamer, Petrova, and Mignosa 2006, 29). But some countries, even when they have no regional level, such as those in Figure 3, spend more at decentralized levels of government. Portugal, which is in a similar situation to Romania, is one of the countries in which this pattern of distribution is more marked.

\section{A polarised and diffuse field of cultural organizations and facilities}

Organizations and facilities for creative activity and cultural production and dissemination occupy an increasingly important position in European discussion on culture, having emerged as an active instrument of national and territorial development. This section analyses a set of data which describes cultural organizations and facilities operating in Portugal, with the main aim of understanding recent trends.

It is important to clarify the concept of 'facility' used here, given that there is no broad conceptual agreement on the term (a fact not unconnected with the diversity of definitions of cultural guidelines themselves ${ }^{12}$ ). 'Cultural facility' is here taken to mean a collective (private or public) space, which promotes creative activity, the promotion and dissemination of culture and cultural events, and combining education and entertainment (Lucchini 1997). 'Cultural organizations' are bodies which undertake creative activities in themselves, having a place of residence (a theatre, an architects' studio, or an alternative space), where teams meet, work and are able to put on their shows, performances and exhibitions, amongst other forms of cultural production. 
As with the pattern described in the previous section, the 2001-2011 period saw an increase in the total number of cultural facilities in Portugal, except for cinemas, and this is no doubt the result of ongoing investment in infrastructure, in some cases with significant support from the Community funds. This investment took place alongside greater diversity in the supply of cultural events and facilities, not unconnected with the dynamics of local government. In relative terms, and not counting the numbers relating to libraries (information on which is lacking in the latest data from the INE, Statistics Portugal) there was a $42 \%$ growth in cultural facilities over the decade.

The distribution of cultural facilities and organizations in 2011 (see Figure 4) was very uneven, with far higher concentrations in the Lisbon and Tagus Valley region, reflecting the territorial impact of the two large metropolitan areas, Lisbon and Porto. In addition to this polarisation in terms of location, the region surrounding the capital is over-represented. These trends are shared with other countries (Markusen and Schrock 2006). In the same way, there is a strong contrast between inland and littoral regions, with a preference for location in the latter. This can be explained by the population density of those regions and by central and local government's public policies for the promotion of culture (Figueiredo and Babo 2015).

In the decade under study several spaces housed different types of facility within them, with a clear emphasis on auditoria, multi-use halls, theatres and cine-theatres, in an overall trend which points to multi-functionality and cross-fertilisation in terms of uses, genres and audiences. The hybrid nature of facilities reflects both the closer relationship between economy and culture and the focus of intersectoriality as the emerging strategy for the cultural field (Santos 2007). Artistic genres, vocational and occupational profiles of creators, and the functions of infrastructure are all combined, in a commitment to flexibility as the watchword for action and the driver for ongoing development (Gomes, Lourenço, and Martinho 2006).

A comparative analysis of the geographical organisation and size of cultural facilities allows us to identify some of the more established characteristics of the Portuguese cultural field: the importance of the third sector in culture; the resilience of certain forms of popular culture and cultural co-operatives, and the variety of cultural facilities and organizations scattered throughout the country, operating in local communities, and not present in official statistics. This dispersed and sometimes informal fabric reflects a social and territorial chessboard in which diffuse urban development, in the interstices of the countryside, creates a kind of continuous city with widely dispersed centres.

The higher spatial concentration in urban centres and in particular in the capital, as previously mentioned, should not blind us, however, to the results of cultural decentralisation and democratisation, nor to the above-mentioned hybrid nature of a cultural fabric with traditional features and the establishment of new spaces and enclosures throughout the territory. In 2013 and 2014 the 308 local

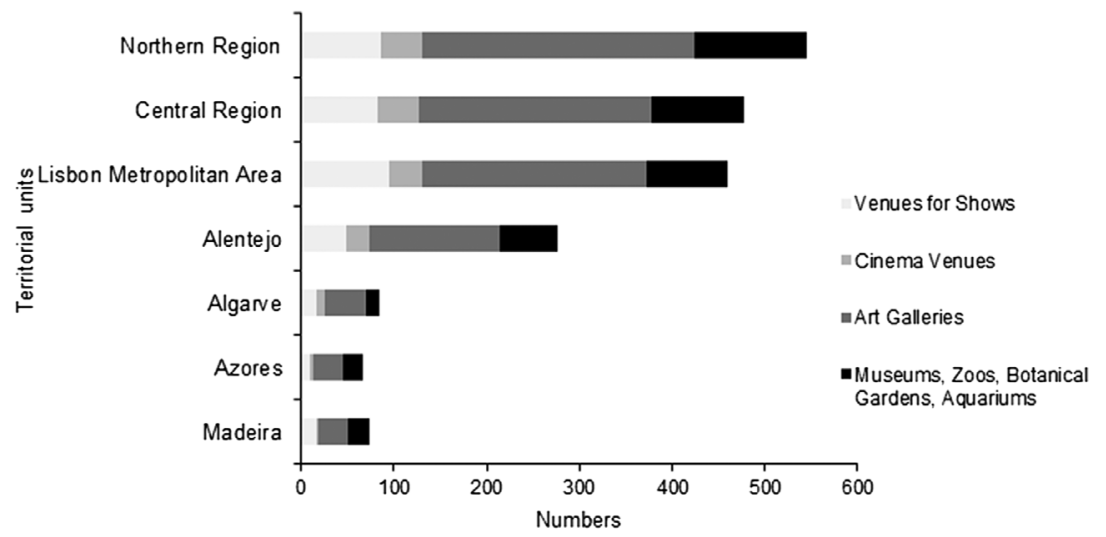

Figure 4. Cultural facilities in 2015, by Nomenclature of Territorial Units for Statistics (NUT). Source: Instituto Nacional de Estatística (Statistics Portugal).

Notes: NUT is the acronym for Nomenclature of Territorial Units for statistics. Data on museums refer to 2014. 
authorities were asked about the facilities they managed. Even though only 120 replied, they accounted for a total of 2478 facilities. This number alone, which excludes data from Lisbon and Porto, includes more variety than that which is found in existing databases. To sum up, undercounting ${ }^{13}$ in this field marginalizes a vast number of facilities, excluding them from public policies as if they were invisible nodes of an underground network. This means that they escape efforts to link them together, while contributing to 'socio-cultural intervention', the 'dynamization of community life', and 'localist' interests and capital (Garcia and Sécio 2007).

A sample survey of some 863 private and public organizations carried out by the Directorate-general for the Arts, Secretary of State for Culture (DGArtes-SEC) for the period 2000-2013 reveals the dynamism and diversity of Portuguese artistic and cultural organizations operating formally or informally in the country. This source shows that at least half of these were set up in the last thirteen years (Borges and Lima 2014). The organizations are mainly non-profit cultural associations, and they cover a range of artistic forms: from theatre (245) to mixed disciplines (222), music (174), fine arts (81), dance (62), architecture (29), design (21), photography (19) and the digital arts (15).

Between 2010 and 2012, 287 cultural organizations operated with regional government support (Borges and Lima 2014). This enables us to reach a judgement that these organizations help to counteract the excessive polarisation of cultural organizations and facilities around Lisbon and Porto, by taking advantage of broader regional creative dynamics. The operation of cultural organizations in a more local context exposes residents to associative and participative forms of socialisation with art, so-called 'neighbourhood socialization', as exemplified in theatre groups (Lopes and Dias 2014). Brass bands, folk dancers, traditional festivals, and semi-professional theatre groups cement the relationship of cultural organizations and their local audiences, fulfilling a social role which goes well beyond the profit-oriented approach, being based rather on a philosophy of inclusion and the inter-generational sharing of experience.

In turn, cultural organizations supported and approved by DGArtes-SEC are employers with a large number of temporary and permanent workers and, as in other European contexts, they develop bonds of 'relational symmetry' with the local population, the semi-professionals and volunteers who share artistic experiences (Urrutiaguer and Philippe 2012). In 2012-2013, cultural organizations supported by the State numbered 146, and their main activities were theatrical, dance, and musical performances, and exhibitions, at home and abroad (Costa, Borges, and Graça 2014). Cultural organizations that have internationalised seem to refocus their activity in times of crisis and severe financial strain, in order to consolidate the trajectories of their leaders and teams. Internationalisation accounts for a significant proportion of activity for a number of Portuguese entities involved in the creation and production of culture, particularly in the 'Ibero-american' case studied here. Between 2012 and 2014, Brazil was the most important destination for bodies funded by DGArtes, with a total of 98 highly diversified projects, initiatives and events involving many different artistic sectors (Garcia et al. 2014).

There are two key concepts applicable to any attempt to make European comparisons. On the one hand, the consolidation of new cultural domains and facilities, based on a flexible, hybrid and reticular model, place Portugal in the European context. But, on the other hand, Portugal also lies at some distance from other countries, a factor which has been exacerbated by the recent crisis: low levels of qualifications of human resources, who are increasingly vulnerable; difficulties in moving from officially scheduled cultural facilities networks to networks actually set up, reflected, for example, in limited identification of international partners for applications for Community programmes, particularly those applicable to facilities programming; decline or even withdrawal in the public supply of services, to the detriment of an integrated cultural policy. ${ }^{14}$

\section{Available information on cultural practices and attendance at cultural facilities}

The main trend in Portugal over the last two decades as far as attendance at cultural facilities is concerned (museums, theatres and other venues for shows, cinemas), has been sustained growth, observable in all sub-areas, with a clear change in the threshold between 1990 and 2000. It has continued 
up until the most recent years for which information is available. Within this general trend there are, however, some differences which need to be pointed out.

In the case of live shows, there has been gradual growth in the early 2000s, reaching its peak in 2008 $(11,104,322$ entrance tickets in total; $4,954,433$ for musical shows; $1,850,332$ for theatre). This trend reflects the emergence and expansion of a specific market, for example popular music concerts (see Endnote 9). In recent years there has been some variation in this trend, with an overall reduction of over 20\% in spectator numbers between 2008 and 2011, and then some recovery until 2014 (10,729,580 entrance tickets, the second best year in the whole period). Despite falling attendance for a few years, which is most likely related to the Portuguese losing purchasing power after 2008, the number of entrance tickets at the beginning of the 2010 s is equivalent to that in the mid-2000s and might actually be growing once again from 2014 onwards.

Regarding cinema, the best attended form of cultural consumer product outside the home, there was accelerated growth from the mid-90s onwards, following decades of declining popularity. Cinemagoing recovered a significant part of its audience in a short space of time, reaching a new peak at the turn of the century (approximately 19,500,000 entrance tickets in the years 2000 and 2001). This was when new spaces for cinema consumption emerged, with the rearrangement of existing cinemas and the widespread opening of multiplexes in shopping centres. The gradual decline which has taken place since then once again reflects changes in the way cinema is consumed, as domestic viewing increased with the expansion of cable channels and new digital media.

On balance, the 20-year pattern of growth in cultural consumption can be seen to have been interrupted by the financial crisis from 2008 onwards (and earlier in the case of cinema), but the effects of the crisis have not produced a reversal, but rather have had a relative impact according to the domain under study. During this period increasing numbers sought entertainment and leisure outside the home, and new urban cultures even emerged (Fortuna and Silva 2002).

Alongside the growth in cultural practices outside the home, there has also been growth in domestic cultural consumption, in this case accompanied by new forms of reception based on multiple new types of media formats providing access to audio-visual content.

It is no surprise that television is the common media format for almost all households. More important from the point of view of changing cultural habits, however, is the general spread of formats such as cable television and computers, which were present in $10 \%$ of households in the mid-90s but represented over $50 \%$ by the beginning of the 2010 s. The pattern revealed by these indicators points to the influence of digital media for the dissemination of culture and implicitly therefore to greater choice of content for consumers (INE 2002, 2007, 2012). To a greater or lesser degree, other formats became widespread among Portuguese families, such as DVD players and video recorders, photographic equipment, CD players (already in decline) and, at a lower level, video material. Based on available indicators we may conclude that cultural activities inside and outside the home did not displace one another, given that, at least in overall terms, there were clear signs of growth in both of them during the period under study.

A fundamental aspect of this process is the rapid growth in the use of computers and access to the Internet (INE 2002-2015). Between 2002 and 2015, the number of households using the Internet more than quadrupled (from 15 to 70\%). We should also note that in terms of comparing the cultural and creative sectors and cultural and leisure content, there was increasing use of gaming consoles. The rapid spread of these technological devices and the presumed growth in the corresponding access to digital content cannot however be understood in linear fashion. If we examine the profile of Internet users, we may observe a clear conditioning effect of traditional explanatory variables for differentiated cultural practices, such as age and educational attainment levels. As is to be expected, Internet use is associated with youth and high levels of educational attainment. Note that the number of Internet users as a percentage of the population touched the threshold of 50\% in 2010, but that for the 45-54 years age group that threshold was only reached in 2012. The generational effect is accordingly rather pronounced.

In this connection, and although this article does not claim to address this issue, it might be appropriate to ask how the financial crisis of 2008 interacted with the increasing take-up of digital media by the Portuguese, just as the same question was posed for Spain (Ariño Villarroya 2015). Especially if we 
bear in mind that the decline in the consumption of analogue cultural goods may have been offset by less expensive options, for example free online access to books, films, music, and shows, and the purchase of e-books.

Comparative studies have highlighted the persistence of social inequality in cultural practices (Prieur and Savage 2011; Purhonen and Wright 2013), and these in turn are reflected in a difference between more regular cultural practices in central and northern European countries and less regular in the South (Szlendak and Karwacki 2012) In this context, there is an important line of research associated with the implementation of cultural policies at the international level involving 'audience building', in the current English expression (cf. Bamford and Wimmer 2012; Potschka, Fuchs, and Królikowski 2013). For a comparative analysis of Portugal and Europe, the three surveys on cultural practices carried out by Eurobarometer are recommended (Eurobarometer 2002, 2007, 2013). ${ }^{15}$

A general observation makes it clear that cultural practices among the Portuguese are well below the average for all EU countries, with a percentage varying between $44 \%$ (attending a dance show) and $85 \%$ (watching a cultural show on television). It is to be noted that the differential falls according to the frequency of the cultural activity under consideration (or how 'less rare' it is); and this in turn produces a higher differential for activities outside the home. A second observation is that there is a growth trend from 2002 to 2007, followed by a decline from 2007 to 2013 - which applies to most activities and countries. These indicators are present for Portugal, along with the trends in attendance at cultural facilities outlined above and with the high point of culture and leisure spending in household budgets attained in the mid-2000s.

\section{Conclusion}

The three sections of this article provide a panorama of culture in Portugal over the last 20 years, covering the aspects we set out to examine: institutionalisation of cultural policy, public expenditure, the network of cultural facilities and organizations. The main conclusion to be drawn from this analysis is that two antagonistic trends are present, with certain observable processes taking place in between them.

From the 1990s until 2008 there was overall growth in investment, in several areas: an increase in the funds invested in culture by the local government and the State; expansion and improvement of the network of more traditional facilities (libraries, museums, archives, cine-theatres), which the country needed; the emergence of multi-purpose spaces with multiple uses; an overall increase in attendance at cultural facilities, and a rapid transition to digital culture; cultural organizations forming a material basis for cultural intervention and providing interfaces between audiences and cultural production; substantive involvement of cultural actors with the ability to reflect and to network, at various levels, from the national to the international.

The other major trend is strongly tied in with the international financial crisis of 2008 and the subsequent sovereign debt crisis of 2011. This chain of events necessarily put a brake on earlier tendencies and led to: declining budgets; disinvestment from, or cancellation of, various culture projects; a marked bi-polarisation in the geography of productive and creative organizations; discontinuities in the definition of cultural venues' missions and programmes, thereby distorting their intended uses and even their normal operation; persistent asymmetry in citizens' access to the diversity of cultural goods, which continue to be enjoyed mainly by those with higher educational attainment levels. As is readily perceptible, this is a trend which brings segregation, both social and spatial. Helping somewhat to attenuate this contrast are intermediate areas, basically supported by the third sector, ranging from foundations to cultural co-operatives. The co-operative segment is a more submerged and varied fabric, but a resilient one, because it is embedded in local social contexts, and benefits from its surrounding regions, in terms both of public support and the possibilities for co-operation with other organizations.

Based on the overall assessment of that which was achieved in a growth cycle, in contrast to a time of containment, discontinuity and change, culture in Portugal faces a number of dilemmas and challenges. One such challenge, examined here, is flexible working. On the one hand, flexible working arrangements provide a foundation for organizational renewal and adjustment, combining the aspirations of their 
founders with artistic and organizational models which adapt and adjust to co-opted forms of support, taking advantage of opportunities for internationalisation and partnerships. On the other hand, the decrease in public funding increases cultural organizations' vulnerability and is potentially demotivating. And if a time of crisis and restrictions make voluntary work particularly appropriate, how are we to distinguish such casual labour from career work, including the management of flexible hours? The risk is that cultural actors may become somewhat indistinguishable, even though their experience and career trajectories in fact mean they can contribute in very diverse ways to sustaining the dynamism, multiplicity and contemporary meaning of the cultural sector.

As the article mentions, the Portuguese population's level of cultural activity is amongst the lowest in the European Union. As also highlighted here, Portugal has structural problems of educational attainment, and in the context of the 28 member-states is still struggling with a high proportion of its population having low educational qualifications. It not only has the lowest percentage of people who have completed secondary education, but also one of the highest early dropout levels. It is thus not surprising that cultural practices in Portuguese society are unequally distributed in social terms, with the differences being less marked only among younger and better educated groups. While the rapid transition to the digital era is a factor in Portugal's modernisation, here too there are signs that a degree of segregation is emerging. As mentioned above, the cultural practices indicator for the Portuguese population is low in the European context and is associated with greater levels of social inequality in access to culture. Among younger and better qualified groups patterns of cultural practices are closer to the European level.

This combination of factors, exacerbated by the financial crisis, suggests that the discrepancies between the Portuguese cultural scene and other European states may re-emerge. As previously observed, the continual decline in central and local government budgets gives rise to severe limitations on government intervention, encouraging mainly random individual measures subject to permanent contingency. Such actions cannot be described as constituting a strategically planned, properly articulated and continuity-based cultural policy. It should be noted, incidentally, that the suspension of the Ministry of Culture between 2011 and 2015, together with the merging of some departments which had sectoral responsibilities for heritage matters, may have effectively dismantled previously established institutional arrangements. It is in these circumstances that the tendency emerges, in most European policies, to measure the success of cultural policy in terms of its contribution to economic growth. In a time of (re-)adjustment, cuts in funding and containment of expenditure, an ambiguity develops between that which is inevitable and imposed by the crisis and that which derives from reasoned measures for the cultural sector. In the current situation of financial crisis, the risks for the cultural sector in Portugal are that governments will remove themselves from mediating and regulating overall cultural flows, allowing these to be dominated by private sector interests (which are mainly oriented to the culture industries and lately to the creative industries).

Finally, it is clear throughout this article that the poor quality of information on the cultural sector points to several difficulties, from conceptual definition and harmonisation to the reliability of statistical surveys. These are obstacles that risk producing intervention which is not aware of the context it is going to affect. Although there is considerable accumulated knowledge of the reality of cultural life, there are still some fundamental gaps: the country still needs a cultural map, and no national survey has yet been conducted of cultural practices, unlike other European countries.

\section{Notes}

1. Indicates the percentage of persons aged 18-24 who stopped attending school without completing their secondary education.

2. Eurostat - National Statistic Institutes, PORDATA. In 2014 the highest rate of early dropout from school and training programmes was found in Spain (22.3\%) and, as in Italy, the percentage of the population with secondary education is under $60 \%$, which is below the EU average (75.8\%).

3. Equatorial Guinea adopted Portuguese as an official language in 2010 (after Spanish and French). 
4. The Socialist Party (Partido Socialista) (PS) was founded in 1973 and is an affiliate of the Socialist International and the Progressive Alliance. It is a member of the European Socialist Party.

5. The Social Democrat Party (PSD) was founded in May 1974, under the name Popular Democratic Party (Partido Popular Democrático) (PPD). It is an affiliate of the Centrist Democrat International and member of the European People's Party. For a number of years it adopted the initials PPD-PSD.

6. The CDS - Popular Party (CDS - Partido Popular) (CDS-PP) was founded in July 1974, under the name Party of the Social Democratic Centre (Partido do Centro Democrático Social) (CDS). It later changed its name to Popular Party (Partido Popular) (maintaining the initials CDS-PP). It is affiliated to the International Democrat Union and a member of the European People's Party.

7. Council of Europe/Ericarts. http://www.culturalpolicies.net/web/countries-profiles-cr.php.

8. See, by way of example, the Reading Promotion Programme launched in 1997 and aimed mainly at municipal libraries, which currently 'has no overall budget of its own' (in http://www.dglb.pt/sites/DGLB/Portugues/livro/ promocaoLeitura).

9. Source: GEPAC/Ministry of Culture.

10. In 2013 there was a break in the series at source. For the purposes of this article two main changes were made: a different ordering of the domains and sub-domains previously treated in accordance with the ESSNet-Culture report (Bina et al. 2012); and the inclusion of three new domains - architecture, design and crafts. Despite this break in the series the comparison holds good, although some caution is called for, bearing in mind the main implication for the total values obtained, which is the increase resulting from the addition of these three domains. Together they represent no more than $3 \%$ in either of the two years in question.

11. Council of Europe/Ericarts. http://www.culturalpolicies.net/web/statistics-funding.php.

12. European statistical information has no common definition of the concepts of facility and creative organisation and cultural and artistic production and dissemination.

13. A cultural map of the country is yet to be drawn (although there is a current project at the Instituto Nacional de Estatística (Statistics Portugal) to geotag cultural facilities).

14. The limited supply of cultural statistics on facilities and organizations, alongside the need to define public policies for the sector (Hasitschka, Tschmuck, and Zembylas 2005) demands uniform European statistics as far as typologies and tools of quantitative analysis are concerned. Only in this way will it be possible to ensure the reliability and comparability of results and measure the significance of the local activity of cultural facilities and organizations, as well as the consequences of that activity for strengthening social cohesion in European societies. For a comparative perspective on the specific case of organizations dedicated to architecture, with the ability to achieve reputational impact internationally, see Garcia et al. 2014.

15. This source is of limited value, particularly on account of the small size of its samples at the national level. It identifies major trends rather than providing rigorous numerical data.

\section{Disclosure statement}

No potential conflict of interest was reported by the authors.

\section{Funding}

This work was supported by the ERDF Technical assistance Operational Programme 2007-2013 (POAT FEDER).

\section{Notes on contributors}

José Luís Garcia is a Senior Research Fellow at the Institute of Social Sciences, University of Lisbon (ICS-ULisboa). His main research interests are in culture and communication studies; social studies of science and technology; and social theory. Recent publications include La Contribution en ligne: Pratiques participatives à l'ère du capitalisme informationnel (2014, co-editor with S. Proulx e L. Heaton), and The Technological Society in the 21st Century (2013, co-editor with H.M. Jerónimo and C. Mitcham).

João Teixeira Lopes is head of sociology department and full professor at the Faculty of Arts of the University of Porto (FLUP). He has published 23 books (alone or in co-authorship) in the fields of sociology of culture, city, youth and education, as well as museology and territorial studies. He is currently working on brain drain and academical mobility from Portugal to other european countries and in social inclusion through music.

Teresa Duarte Martinho is a Post-doctoral Researcher at the Institute of Social Sciences, University of Lisbon (ICS-ULisboa). She is currently researching the way cultural sector policies in Portugal have addressed and approached digital culture. She was previously a researcher at the Portuguese Observatory for Cultural Activities (OAC), from 1996 to 2011 . She is 
the author of various works (alone or in co-authorship) in areas such as the cultural and artistic occupations; processes of mediation of art and science; cultural organizations and cultural reception.

José Soares Neves is a Post-doctoral Researcher at the Centre for Research and Studies in Sociology (CIES-IUL), in the University Institute of Lisbon, and an Invited Assistant Professor at the Department of Sociology of the University Institute of Lisbon (ISCTE-IUL). He has published several works (alone or in co-authorship) in the fields of sociology of culture and cultural policies in the domains of the book, reading and museums. He was previously a researcher at the Portuguese Observatory for Cultural Activities (OAC). Currently his main research areas are reading in the digital age and publics of the national museums.

Rui Telmo Gomes is a Post-doctoral Researcher at the Centre for Research and Studies in Sociology (CIES-IUL), in the University Institute of Lisbon, currently focused on the relation between cultural policies and participation, community arts and non-professional artistic production. He has been recently involved in research on Punk culture in Portugal and also on transitions to new attractive professional worlds for young people in the creative sector. He was previously member of the Observatory for Cultural Activities' research team.

Vera Borges is a Post-doctoral Researcher at the Centre for Socioeconomic and Territorial Studies in the University Institute of Lisbon (DINÂMIA'CET-IUL) and Associate Researcher at the Institute of Social Sciences, University of Lisbon (ICS-ULisboa). She is the author of various works on professions, organizations and artistic labour markets published in Sociology of Art, Portuguese Journal of Social Sciences, Professions and Professionalism. She is currently working on collaborative art and territory: between theater and architecture in regional, national and international scenarios.

\section{References}

Albuquerque, L., 2011. "A cultura como categoria de intervenção pública no tempo e no território [Culture as a Public Intervention Category in Time and Territory]."Tese de Doutoramento em Sociologia, Faculdade de Letras da Universidade do Porto [Doctoral thesis in sociology, University of Oporto, Faculty of Arts].

Alexander, V. D., and Anne E. Bowler. 2014. "Art at the Crossroads: The Arts in Society and the Sociology of Art." Poetics, 43 (1), 1-19.

Ariño Villarroya, A., 2015. "La cultura en España en la era digital [Culture in Spain in the digital age]."In España 2015: Situación social [Spain 2015: Social Panorama], coord. by, C. T. Albero, 1356-1379. Madrid: Centro de Investigaciones Sociológicas.

Bamford, A., and M. Wimmer. 2012. EENC Short Report on Audience Building and the Future Creative Europe Program.

Barreto, A., ed. 1996. A Situação Social em Portugal. 1960-1995 [The Social Situation in Portugal, 1960-1995]. Lisboa: Imprensa de Ciências Sociais.

Bennett, O. 2009. "Cultural Policy, Cultural Pessimism and Postmodernity." International Journal of Cultural Policy 4 (1): $67-84$.

Bina, V., P. Chantepie, V. Deroin, G. Frank, K. Kommel, J. Kotýnek, and P. Robin 2012. ESSNet-culture Final Report. Luxemburg: ESSnet Culture and Eurostat. http://ec.europa.eu/culture/library/reports/ess-net-report_en.pdf.

Borges, V., and T. Lima. 2014. "Apoio público, reconhecimento e organizações culturais: O caso do teatro [Public Support, Recognition and Cultural Organizations: The Case of Theater]." Análise Social 213, XLIX (4.`): 926-952. http://analisesocial. ics.ul.pt/documentos/AS_213_d04.pdf.

Conde, I. 2000. "A nossa múltipla condição [Our Diverse Condition]." In M. G. M. Ventura, coord. by, A Definição dos espaços Sociais, Culturais e Políticos do Mundo Ibero-Atlântico (de finais do séc. XVIII até hoje) [The Definition of Social, Cultural and Political Spaces in the Iberian Atlantic World (from the end of the Eighteenth century to Present)], 95-110. Lisboa: Edições Colibri.

Costa, P., V. Borges, and S. Graça. 2014. "Structural Change and Diversity in Theatrical Groups: An Empirical Study in the Lisbon Area." Portuguese Journal of Social Sciences 13 (1). http://www.intellectbooks.co.uk/journals/view-Article,id=17643/.

Council of Europe. 2009. "Summary of Questionnaire on the Financial Crisis and Culture." Culture Watch Europe (3).

Cummings, M. C., and R. S. Katz. 1989. "Relations between Government and the Arts in Western Europe and North America." In Who's to Pay for the Arts? The International Search for Models of Arts Support, edited by M. C. Cummings and J. M. D. Schuster, 5-14. New York: American Council for the Arts.

D'Angelo, M. 2000. Politiques Culturelles en Europe: La Problématique Locale [Cultural Policies in Europe: Local Issues]. Strasbourg: Council of Europe Publishing.

De Voldere, I., E. Durinck, K. Mertens, C. Cardon, T. Maenhout, S. Warmerdam, M. Versteegh, and E. Canton. 2013. Survey on Access to Finance for Cultural and Creative Sectors. Brussels: European Commission.

Eurobarometer. 2002. "Eurobarometer 56.0: Information and Communication Technologies, Financial Services, and Cultural Activities." http://ec.europa.eu/public_opinion/archives/eb/eb56/eb56_en.htm.

Eurobarometer. 2007. "Special Eurobarometer 278/Wave 67.1: European Cultural Values." http://ec.europa.eu/public_ opinion/archives/ebs/ebs_278_en.pdf.

Eurobarometer. 2013. "Special Eurobarometer 399/Wave EB79.2:TNS Opinion \& Social."http://ec.europa.eu/public_opinion/ archives/ebs/ebs_399_en.pdf. 
Figueiredo, A., and E. P. Babo. 2015. "Territorialização das Políticas Públicas: Inovação e Cultura [Policies'Territorialization: Innovation and Culture]." In Afirmar o Futuro. Políticas Públicas para Portugal [Asserting the Future: Public Policy for Portugal], edited by V. Soromenho-Marques and P. T. Pereira, 234-263. Lisboa: Fundação Calouste Gulbenkian.

Fortuna, C., and A. S. Silva, eds. 2002. Projectos e Circunstância: Culturas Urbanas em Portugal [Project and circumstance: urban cultures in Portugal]. Porto: Edições Afrontamento.

Garcia, O., and J. Sécio. 2007. "Para uma análise tipológica do movimento associativo: um estudo diagnóstico das associações culturais e recreativas na cidade de Lisboa [For a Typological Analysis of the Associative Movement: A Diagnostic Study of the Cultural and Recreational Associations in Lisbon]." OBS - Observatório das Actividades Culturais 15: $22-41$.

Garcia, J. L., J. T. Lopes, R. T. Gomes, J. S. Neves, T. D. Martinho, and V. Borges. 2014. Mapear os Recursos, Levantamento da Legislação, Caraterização dos Atores, Comparação Internacional [Mapping resources, Survey of the legislation, Description of main actors, International comparison]. Lisboa: Secretário de Estado da Cultura/Gabinete de Estratégia, Planeamento e Avaliação Culturais.

Gomes, R. T., V. Lourenço, and T. D. Martinho. 2006. Entidades Culturais e Artísticas em Portugal [Cultural and Artistic Organizations in Portugal]. Lisboa: Observatório das Actividades Culturais.

Hasitschka, W., P. Tschmuck, and T. Zembylas. 2005. "Cultural Institutions Studies: Investigating the Transformation of Cultural Goods." The Journal of Arts Management, Law and Society 35 (2): 147-158.

INE. 2002-2015. Inquérito à Utilização de Tecnologias de Informação e Comunicação pelas Famílias. [Survey on the Use of Information and Communication Technologies by Families]. Lisboa: INE.

INE. 2002. Inquérito aos Orçamentos Familiares 2000 [Household Budget Survey 2000]. Lisboa: INE.

INE. 2007. Inquérito às Despesas das Famílias 2005/2006 [Family Expenditure Survey 2005/2006]. Lisboa: INE.

INE. 2012. Inquérito às Despesas das Famílias 2010/2011 [Family Expenditure Survey 2010/2011]. Lisboa: INE.

Inkei, P. 2010. "The Effects of the Economic Crisis on Culture."In Culture Watch Europe 2010. Culture and the Policies of Change. Conference Reader, edited by AAVV, 56-71. Brussels: Council of Europe and others.

Inkei, P. 2011. Results of a 2011 Survey with Governments on Culture Budgets and the Finantial Crisis and Culture. Strasbourg: Council of Europe.

Klamer, A., L. Petrova, and A. Mignosa. 2006. Financing the Arts and Culture in European Union. Brussels: European Parliament.

Lopes, J. T., and S. J. Dias. 2014. "O público vai ao teatro: uma etnografia dos públicos em ação [The Public Goes to the Theatre: An Action-oriented Ethnography on Publics in Action]." Sociologia, Problemas e Práticas 74: 51-72.

Lucchini, F. 1997. “Les équipements culturels au service de la population des villes [Cultural Facilities Serving the Population of Cities]." European Journal of Geography. Dossiers 'Les problèmes culturels des grandes villes', Colloque. http://cybergeo. revues.org/4988.

Markusen, A., and G. Schrock. 2006. "The Distinctive City: Divergent Patterns in Growth, Hierarchy and Specialization." Urban Studies 43 (8): 1301-1323.

Martinho, T. D. 2016. “Em linha com a União Europeia? O digital na política para a cultura em Portugal [In line with the European Union? Digital and Cultural Policy in Portugal]." In Cultura e Digital em Portugal [Culture and Digital in Portugal], coord. by., T. Martinho, J. T. Lopes, and J. L. Garcia. Porto: Afrontamento.

Martinho, T. D., and J. N. Matos. 2014. “Como governar o único teatro de ópera em Portugal? A incerteza permanente do Teatro Nacional São Carlos à luz da legislação [How to Govern the Only Opera Theatre in Portugal? The Ongoing Uncertainty of National Theatre of São Carlos]." Revista Lusófona de Estudos Culturais |Lusophone Jornal of Cultural Studies 2 (2): 165-187. http://estudosculturais.com/revistalusofona/index.php/rlec/article/view/117.

Menger, P.-M. 2010. "Cultural Policies in Europe. From a State to a City-centered Perspective on Cultural Generativity." GRIPS (Graduate Institute for Policy Studies) Discussion Paper 10-28. http://www3.grips.ac.jp/ pinc/data/10-28.pdf.

Morató, A. R. 2012. "The Culture Society: A Heuristic for Analyzing Cultural Change in the Global Age." In Sociology Today: Social Transformations in a Globalizing World, edited by A. Sales, 316-338. London: Sage.

Neves, J. S. 2010. "Políticas culturais locais e financiamento da Cultura: crescimento e planeamento [Local Cultural Policies and Financing of Culture: Growth and Planning]." Trajectos 16: 125-130.

Pinto, J. C. 2012. Culture and the Structural Funds in Portugal. EENC.

Potschka, C., Fuchs, M., and Królikowski, A., 2013. "Review of European Expert Network on Culture's Audience Building and the Future Creative Europe Programme, 2012." Cultural Trends 22: 3-4. http://www.ingentaconnect.com/content/ routledg/ccut/2013/00000022/f0020003/art00020.

Prieur, A., and M. Savage. 2011. “Updating Cultural Capital Theory: A Discussion based on Studies in Denmark and in Britain." Poetics 39 (6): 566-580.

Purhonen, S., and D. Wright. 2013. "Methodological Issues in National-comparative Research on Cultural Tastes: The Case of Cultural Capital in the UK and Finland." Cultural Sociology 7 (2): 257-273.

Santos, B. S. 1994. Pela Mão de Alice. O Social e o Político na Pós-Modernidade [By Alice's Hand - Society and Politics in Postmodernity]. Porto: Edições Afrontamento.

Santos, M. L. L. 2007. "Cultura/Economia - uma relação a revisitar [Culture/Economy - A Relation to Revisit]." OBS Observatório das Actividades Culturais 15: 3-9.

Santos, M. L. L. (ed.), L. Antunes, I. Conde, A. F. Costa, E. Freitas, R. Gomes, C. Gonçalves, and H. S. Gonçalves. 1998. As Políticas Culturais em Portugal [Cultural Policies in Portugal]. Lisboa: Observatório das Actividades Culturais. 
SICA. 2010. The Economic Crisis and the Prospects for Art and Culture in Europe. SICA. http://www.culturalpolicies.net/web/ files/83/en/en_crisis_and_prospects_for_art_and_culture_in_europe_oct2010.pdf.

Silva, A. S. 2004. "As redes culturais: balanço e perspectivas da experiência portuguesa, 1987-2003 [Cultural Networks: An Overview and Prospects of the Portuguese Practice, 1987-2003]." In Públicos da Cultura [Culture Audiences], edited by AAVV, 241-283. Lisboa: Observatório das Actividades Culturais.

Silva, A. S., E. P. Babo, and P. Guerra. 2015. "Políticas culturais locais: Contributos para um modelo de análise [Local Cultural Politics: Contributions to an Analytical Model]." Sociologia, Problemas e Práticas 78: 105-124.

Soromenho-Marques, V., and P. T. Pereira. 2015. Afirmar o Futuro. Políticas Públicas para Portugal [Asserting the Future: Public Policy for Portugal]. Lisboa: Fundação Calouste Gulbenkian.

Szlendak, T., and A. Karwacki. 2012. "Do the Swedes Really Aspire to Sense and the Portuguese to Status? Cultural Activity and Income Gap in the Member States of the European Union." International Sociology 27 (6): 807-826.

Urrutiaguer, D., and H. Philippe. 2012. Territoires et ressources des compagnies en France [Company Territories and Resources in France]. Paris: Deps-MCC. http://www.culturecommunication.gouv.fr/Politiques-ministerielles/Etudes-et-INEstatistiques/ Articles/Culture-etudes-2012-1.

Viegas, J. M. L., and A. F. Costa. 2000. Crossroads to Modernity: Contemporary Portuguese Society. Oeiras: Celta. 